\title{
The Influence of Weather Factors to Mood and Human Behavior on the Stock Market Indices Performance by the Tendency towards Geographical Location
}

\author{
Lai Ferry Sugianto*, Chai Liang Huang \\ Department of Finance, College of Management, National Chung Cheng University, Taiwan
}

Received May 28, 2020; Revised June 24, 2020; Accepted August 10, 2020

Copyright $\mathrm{C} 2020$ by authors, all rights reserved. Authors agree that this article remains permanently open access under the terms of the Creative Commons Attribution License 4.0 International License

\begin{abstract}
This research tries to determine the weather factors affect mood and human behavior. Some previous researches find that weather can influence human behavior and mood, like concentration, optimism, self-confidence, aggression, and performance. Many weather indicators can affect human behavior and mood, but only few of them have been investigated. In this paper, we use temperature, precipitation, hours of sunshine, and humidity. Mood and behavior make people make decisions based on such indicators, including the trading decision in the stock market. Therefore, mood and behavior turn the investors to become more irrational. In this research, geographical locations are also being included because the difference in location can make a difference in the climate. By using indices return from 44 countries, we get that higher temperature creates more aggression and makes investors more aggressive and risk-taking, leading to the higher returns, hours of sunshine also make investors more optimistic and less risk-averse which leads to higher returns. Higher humidity also leads to a higher concentration. We also find that in Europe and Asia, the effect of weather variables is much stronger than in other continents. Additional results show that stock markets in Europe and Asia are easily affected by weather factors, and the high elevation also has a more significant effect.
\end{abstract}

Keywords Weather, Human Behavior, Mood, Stock Market Indices, Geographical Location

\section{Introduction}

Stock is the equity that is received by stakeholders investing in and used to generate funds from other parties. It represents the residual asset of a company, so it is influenced by a lot of internal and external factors. Many studies want to find the factors affecting the stock prices, but many have not found the correct form of representation factors of stock prices precisely because of the high volatility of the stocks.

Weather is the most challenging factor to be detected in human behavior because it combines interdisciplinary, such as accounting, economics, statistics, psychology, and sociology (Ackert \& Deaves, 2009). The study, which includes human psychology into the finance field, is called Behavioral Finance. However, this study is still widely debated (Wallace, 2010), both by practitioners or academicians, because they still do not trust behavioral finance as a factor that is strong enough to affect stock prices. So many people conduct researches about it and find any evidence that can reinforce the concept of behavior in investments. In his article, Wallace (2010), says that the investors' mood psychological behavior can have a significant impact on markets. People sometimes act irrationally, no exception to the act of buying and selling stocks. This irrationality makes mispricing and bias in stock prices. Mispricing can be affected by under or overreactions to new information (Kent, David, \& Avanidhar, 1998), emotion/mood fluctuations, and projection bias (Mehra \& Sah, 2002).

Mehra and Sah (2002) summarize the mood fluctuations in several different ways, such as individual endogenously determines discount factor (how much effort and resources to spend on creating future appreciation, probabilities of death (epidemics, armed conflicts, and discoveries in medical treatments), projection bias (misprediction in the future sequence of preferences), weather fluctuation (bright versus non-bright days), observations from the psychology literature (mood fluctuation), and other observations (ongoing interactions among investors and human interactions). Many behavioral factors influence the volatility on the stock market, but in this research, we want to prove the correlation between the weather factors, mood, 
and stock prices, represented by indices.

The study that examines the relationship between weather and stock prices is not new longer. David and Tyler (2003) examine the relationship between whether a day is sunny, and stock returns that day at 26 stock index exchanges internationally from 1982-97. They find that sunshine is highly significantly correlated with daily stock returns. Their research proves that people often attribute their feelings to the wrong source, leading to incorrect judgments (misattribution), likes happiness on sunny days than rainy days. In line with this research, Symeonidis, Daskalakis, and Markellos (2010), using the same data of 26 stock indices, add the volatility indices for further support to the previous finding. They conclude that sunny weather influence investors' mood, making them more optimistic and less risk-averse, which leads to higher returns. In the third research, with the different data, Akhtari (2011) tries to imitate the concept of both previous studies and implicate in Dow Jones Industrial Average (DJI) index return data from 1948 until 2010. He finds that hours of sunshine in New York City have a significant correlation with stock prices, and he argues that sunnier day is associated with investors being more willing to make risky investments, such as stocks, as opposed to less risky investments.

Another study tests another weather indicator and finds that it correlates with stock market returns. Cao and Wei (2005), using nine international stock indices, covering eight financial markets in the U.S., Canada, Britain, Germany, Sweden, Australia, Japan and Taiwan, examine the correlation between temperature and stock market returns. They find that temperature is one of the essential meteorological variables affecting people's moods. Low temperature tends to cause aggression, and high temperature tends to cause aggression, hysteria, and apathy. Lower temperature leads to higher stock returns due to investors' aggressive risk-taking, and higher temperatures lead to higher or lower stock returns since aggression and apathy have competing effects on risk-taking.

In these researches, they consider two kinds of weather variables, hours of sunshine, and temperature. However, many weather indicators can be deliberated or tested, especially in the modern era, because in the modern era, many technologies created that can reduce the weather impact, such as air conditioner, heater, and electronic trading, which allows for stock trading indoor. So, now investors do not need to trade in a stock exchange, but they can do trading at their home or office. Furthermore, another consideration is the geographical location. No study includes the geographical location as an important factor, even though the location or region can affect the climate and also influence the weather in a particular area. The climate in a particular region is different from others; it is determined by many factors. The most crucial factor is the earth's position concerning the sun (Boehm, 2002).

In psychological study, there is research that examines the relationship between mood and weather. Howarth and
Hoffman (1984) verify that there is the relationship between mood (concentration, cooperation, anxiety, potency, aggression, depression, sleepiness, skepticism, control, and optimism) and weather (hours of sunshine, precipitation, temperature, wind velocity, humidity, and change in barometric pressure) by testing 24 male university students participated in the study to fulfill course requirements. They find that hours of sunshine affect concentration, skepticism, and optimism, as precipitation affects skepticism, temperature affects concentration, and humidity affects concentration, potency, and sleepiness. So, parallel with this model, it is essential to examine other weather factors that may cause changes in mood in the stock trading, especially with the data in this modern era.

\section{Literature Review}

\subsection{Weather Variables}

Weather consists of many variables and indicators which can be measured, such as sunshine, temperature, precipitation, humidity, moisture, wind velocity, and barometric pressure. These variables are made by people to represent the atmosphere conditions and to measure the weather situations. Barry and Chorley (1970) in their book, explain the meanings of these variables and how to measure them; also Aguado and Burt (2007) add several variables, they are:

Temperature is an index of the average energy of the molecules comprising a substance. The daily mean temperature is defined as the average of the maximum and minimum temperature of the day. Many geographical factors are influencing the temperature; they are latitude, altitude, atmospheric circulation patterns, local conditions, continentality, and current ocean characteristics among coastal locations. Cao and Wei (2005) find that temperature is an essential meteorological variable affecting people's moods. Low temperature tends to cause aggression, and high temperature tends to cause aggression, hysteria, and apathy. Lower temperature leads to higher stock returns due to investors' aggressive risk-taking, and higher temperatures also lead to higher or lower stock returns since aggression and apathy have competing effects on risk-taking. However, Howarth and Hoffman (1984) in psychological paper mention that the high temperature increase the concentration. The higher concentration also can lead to higher stock returns. Overall, the high temperature dominates the effect. So, using global observations, we want to solve this question.

\section{H1: Temperature positively affects the stock market return.}

Precipitation is liquid water or ice that falls to the earth's surface. There are several forms of precipitation, such as 
snow, rain, graupel and hail, sleet, and freezing rain. So, people can measure the precipitation by rain gages for rainfall and snow measurement for snow. Rain gage uses precipitation funnels that have a specific size and mounted at a specific height. Nevertheless, it is different from snow measurement. They use water equivalent, the depth of water that would result if all the snow melts. Howarth and Hoffman (1984) find that precipitation affects skepticism. Their result shows that people become more skeptical in raining days. We expect that the skepticism leads to lower returns because people have doubt in trading stock during the raining days.

\section{H2: Precipitation negatively affects the stock market return.}

The length of daylight or sunshine duration or sunshine hour is measuring the duration of sunshine in a given period for a given on earth, typically expressed as an average of several years, which can also indicate the cloudiness of a location. The length of daylight affects the amount of radiation that is received. The longer the time during which the sun shines, the higher is the quantity of radiation that a given portion of the earth receives. Howarth and Hoffman (1984) also say that the skepticism scale is negatively related to hours of sunshine, hours of sunshine increased, optimism score also increases. In line with the previous researches about behavioral finance, sunshine is highly significantly correlated with daily stock returns (David \& Tyler, 2003).

\section{H3: Sunshine hours positively affect the stock market return.}

Humidity means an expression of the amount of water vapor in the air. There are six expressions which can represent humidity factor, like vapor pressure, absolute humidity, specific humidity, mixing ratio, and relative humidity. All methods have advantages and disadvantages depending on the intended use. We use vapor pressure as one of our indicators. It is simply part of the total atmospheric pressure due to water vapor, which depends on temperature and the density of water vapor molecules. Howarth and Hoffman (1984) argue that decreasing humidity and dropping barometric pressure accompanied lower score on concentration.

\section{H4: Vapor pressure positively affects the stock market return.}

Dang, Gillett, Weaver, and Zwiers (2007) report that globally-averaged instrumental surface temperatures records show increases estimated to be $0.4-0.8^{\circ} \mathrm{C}$ since the late 19th century to the year 2000. Surface air temperatures also show warming trends during the same period if the substantial observed changes in ecosystems under observed historical weather factors can be linked to human activities and not possible to link it with the human behavior.

Barry and Chorley (1970) reveal that some studies try to separate periods to show that is the evidence of climate change happened, and some predict the changes over the next 100 years. Climate changes make some changes to the earth, such as:

1. Atmospheric composition. The increases in the atmospheric concentration of greenhouse gases (mainly $\mathrm{CO}_{2}, \mathrm{CH}_{4}$, and $\mathrm{CFC}$ ) since the growth of industry and population.

2. Temperature and humidity. The northern hemisphere has employed estimates of temperature variations associated with the observed increase of $\mathrm{CO}_{2}$ (emission of greenhouse gases) and regular solar oscillations. The significant predictions are general warming of earth's surface and troposphere by up to more than $12^{\circ} \mathrm{C}$ in some high southern latitudes, more substantial warming of earth's surface and troposphere in higher latitudes in autumn and winter by $4^{\circ}-8^{\circ} \mathrm{C}$, tropical warming less than the global mean by $2^{\circ}-3^{\circ} \mathrm{C}$, amplified warming over northern mid-latitude continents in summer by $4^{\circ}-6^{\circ} \mathrm{C}$, soil moisture increases in winter and decreases in summer in northern mid-latitude continents.

3. Sea level. Sea level is influenced by changes in ocean water mass, changes in ocean water volume, changes in earth crustal level, and changes in the global distribution water.

Weather involves factors both external to and within the climate system (Barry \& Chorley, 1970). External ones include solar variability, astronomical effects of the earth orbit, and tectonic activity. Internal factors include variability within the atmosphere and ocean and their feedbacks. Climatic changes in geological time-scales involve continental drift, volcanic activity, and possible changes in solar output.

\subsection{Geographical Location Variables}

The climate varies in different locations; it is different from others; it is determined by many factors (Boehm, 2002). Climate variability also makes the weather differences. Boehm (2002), in his book, tells the difference between weather and climate. Weather is the condition of the atmosphere in one place during a limited period, but the climate has a different meaning. Climate is the term of weather patterns that an area typically experiences over a long period. The main factor which influences climate is the earth's position concerning the sun; it means that the geographic location takes part in the formation of climate and weather. Four geographical factors can be included in this term; they are region/continent, pole, latitude, and elevation.

1. Latitude. The geographical factors (latitude and elevation) have the most important effect on the local 
climate (Vajda \& Venalainen, 2003). It is explained that different parts of the earth's surface receive different amounts of solar radiation (Barry \& Chorley, 1970). Latitude is very important to control because the geographical situation of a region will determine both the duration of daylight and the distance traveled through the atmosphere by the oblique rays from the sun. During the earth's annual revolution around the sun, the rays fall in a regular pattern ("Continental-scale temperature variability during the past two millennia," 2013). The pattern is correlated with bands, latitude, and zone to describe the climate regions, so within every latitude zone, the climate happens in a particular pattern.

2. Region/continent/zone. Earth's climate has undergone significant climate variations that have yet to be quantified at the continental scale, where climate variability is arguably more relevant to ecosystems and societies than globally averaged conditions ("Continental-scale temperature variability during the past two millennia," 2013). The change in temperature and cooling varies in seven continental-scale regions. Dang, Gillett, Weaver, and Zwiers (2006) also argue that the subsequent influences of the climatic changes on the bio-systems are very different from region to region.

3. Pole/hemisphere. Boehm (2002) argues that the amount of sunlight at the poles varies most dramatically as the revolutions of earth and tilt cause the changing seasons. For a half year, a pole is tilted toward the sun and receives continuous sunlight, when another pole is tilted away and receives little or no sunlight. Temperatures did not fluctuate uniformly among all regions ("Continental-scale temperature variability during the past two millennia," 2013). In the period from around AD 830 to 1100 generally encompassed a sustain warm interval in all four Northern Hemisphere regions. In South America and Australasia, a sustained warm period occurred later. In the Arctic and Europe, the temperatures were relatively high during the first century $\mathrm{AD}$. But, between $\mathrm{AD} 1200$ and 1500, the transition to colder regional climates is evident in Arctic, Europe, and Asia than in North America or Southern Hemisphere. These conditions emphasize that each region has its own condition or climate; it is represented in the different temperatures found.

4. Elevation. Latitude elevation affects the climate because of the relationship between the elevation of the place and the temperature (Boehm, 2002), as elevation increases, the temperature decrease. Even in the high elevation, the sunlight is brighter because the thinner atmosphere filters fewer rays of the sun (solar radiation), this region is colder than the lowland. Elevation, along with local relief and slope aspect, induce very local characteristics on climatology elements (Vajda \& Venalainen, 2003).

\subsection{Stock Market Returns and Indices}

\section{Stock Market Returns}

The purpose of the investment is the return. Many investors invest in many investment instruments in order to get a high return and take benefit from them. So, it is essential to know how to measure returns, especially in stock markets. Return on investment is the change in wealth resulting from the investment (Reilly \& Brown, 2000). Changes in wealth are because of cash inflows (interest and dividends) and changes in the price of the asset. The period the investors are holding their assets is holding period, and the return for that period is the holding period return (HPR) which calculated as follows:

$$
H P R=\frac{\text { Ending value of investment }}{\text { Beginning value of investment }}
$$

HPR helps us express the change in the value of an investment, but it is not practical so many people like changing it into periodical percentage rate, referred to holding period yield (HPY). HPY equals to the HPR minus 1 .

$$
H P Y=H P R-1
$$

This return (HPY) represents total return which is a return objective in which the investor wants to increase the portfolio value by both capital gains and current income reinvestment.

\section{Stock Market Indices}

The index is the stock market indicator which is derived in the same way as an average but from a broader sampling of securities (Finance, 1985). They are many kinds of stock market indices, and they represent the prices of several or many or all the stock prices in particular fields. Jones (2007) defines that composite indexes indicate peaks and troughs in the business cycle and composite economic indexes used as leading indicators that can indicate some variables in economic activity, such as stock prices, customer expectations, money supply, and interest rate spread. In summary, security market indexes are used (Jones, 2007) as benchmarks to evaluate the performance of professional money managers, to create and monitor an index fund, to measure market rates of return in economic studies, to predict future market movements by technicians, and as a proxy for the market portfolio of risky assets when calculating the systematic risk of an asset.

The studies of weather affects stock index returns are investigated by some previous papers. It is started by David and Tyler (2003) and Symeonidis, Daskalakis, and Markellos (2010) who use 26 stock index exchanges, follows by Cao and Wei (2005), using 9 country indices, and the last, Akhtari (2011) use Dow Jones Industrial Average (DJI) index return. It means that indices are 
representative and have been used in many studies about the relation between stock and weather. We follow the previous researches, but we use more indices; 44 stock indices from 44 countries. With more indices we use, we hope that the results are applicable to all countries.

\subsection{Human Behavior, Mood, and the Correlation with Weather}

\section{Human Behavior}

Behavior in humans can be influenced by many factors, such as emotions, moods, attitudes, cultures, and values. It is inherent in human beings to something and makes decisions. The behavior of individuals, practitioners, markets, and managers is sometimes characterized as irrational. Behavioral finance uses insights from psychology to understand how human nature influences the decisions of individual and professional investors, markets, and managers (Ackert \& Deaves, 2009). Behavioral finance is interdisciplinary, which combines accounting, economics, statistics, psychology, and sociology.

Behavioral finance could equip the concept of traditional finance with a set of new lenses, which allows the understanding of many psychological and Behavioral traps involving human actions and emotions (Baker \& Nofsinger, 2010). They explain four critical themes in Behavioral finance; they are:

- Heuristics are means of reducing the cognitive resources necessary to find a solution to a problem which are mental shortcuts that simplify the sophisticated methods ordinarily required to make judgements.

- $\quad$ Framing is a factor influencing people's perceptions and memories of the choice they have.

- Emotions are "animal spirits" which are correlated with universal human unconscious needs, fantasies, and fears that drive many of their decisions. The subtle and sophisticated way our feelings determine psychic reality affect investment judgements. There are six observable features which are defined emotions (Ackert \& Deaves, 2009); they are cognitive antecedents, intentional objects, physiological arousal, physiological expressions, valence, and action tendencies.

- $\quad$ Market Impact. Market prices do not appear to be fair (mispricing). Market anomalies fed an interest in the possibility that they could be explained by psychology.

Mood

Human Behavior can be affected by emotions and moods (Schwarz \& Clore, 1996). George (2000) argues that strong emotions determine short-term action much more strongly than people generally acknowledge, the visceral factor creates difficulty when people make choices that are inter-temporally consistent because the factors frequently change by the environment.
Lucey and Dowling (2005) summarize the connection between mood and economic Behavior. They say that the mood effect is mood misattribution. A bad mood indicates to the decision-maker that something is wrong with the current situation to consider the decision more analytically and critically. A good mood is associated with less careful decision making. Allowing a mood that is unrelated to a decision to affect that decision is what psychologists call mood misattribution. Akerlof and Shiller (2010) add that emotional and intangible factors such as confidence in institutions, illusions about the nature of money, or a sense of being mistreated can affect how people make decisions about borrowing, spending, saving, and investing.

\section{Correlation to Weather}

Researchers have found that the lack of sunshine has been linked to depression (Eagles, 1994) and suicide (Tietjen \& Kripke, 1994). People seem to feel better when they are exposed to more sunshine. Mood research is still controversial because the existence of the proposed mood effects implies profitable trading strategies that do not seem consistent with the arguments of market efficiency (Baker \& Nofsinger, 2010). There are several properties that any good mood measure satisfies, such as weather, length of the day, and sporting results. The earliest study relating to investor mood to stock returns found by Saunders (1993). The result is statistically significant and robust relation, showing that sunnier days correspond to a more favourable return for Dow Jones Industrial Average and the NYSE Index.

A similar study was conducted by David and Tyler (2003), they examine the relationship between sunny day and stock returns of 26 stock exchanges internationally from 1982-97. They find that sunshine is highly significantly correlated with daily stock returns. Their research proves that people often attribute their feelings to the wrong source, leading to incorrect judgements (misattribution), likes happiness on sunny days than rainy days. In line with this research, Symeonidis et al. (2010) add the volatility indices for further support to the previous finding. They conclude that sunny weather influences the mood of investors, making them more optimistic and less risk-averse, which leads to higher returns. It strengthens the finding from Kliger and Levy (2003) which say that the effect of mood on returns is that the mood affects risk aversion and mood effects on the market that are driven by external phenomena such as weather. In the third research, with the different data, Akhtari (2011) tries to imitate the concept of both previous studies and implicate in New York City stock return data from 1948 until 2010. He finds that hours of sunshine in New York City have a significant correlation with stock prices and he argues that sunnier day is associated with investors being more willing to take a risky investment, such as stocks, as opposed to less risky investments.

Another study tests another weather indicator and finds 
that it also correlates with stock market returns. Cao and Wei (2005) examine the correlation between temperature and stock market returns. They find that temperature is one of the important meteorological variables affecting people's moods. Low temperature tends to cause aggression, and high temperature tends to cause aggression, hysteria, and apathy. This evidence provided concludes that there is a correlation between weather, especially sunshine and temperature and market returns. While some people may view this relationship as a spurious correlation produced by data mining, but many researchers believe that it is strong evidence that mood affects prices.

\section{Data}

To examine the relationship between stock indices and weather factors, we combine two data sets. The first one is the monthly stock indices data which we collect from Data Stream from the beginning until December 2013, and the second one is the monthly weather data and some geographical factors from National Climatic Data Center of the National Oceanic and Atmospheric Administration (www.ncdc.noaa.gov) with the same range of time. We follow David and Tyler (2003), Symeonidis, Daskalakis, and Markellos (2010), Cao and Wei (2005), and Akhtari (2011), to pick one corresponding city of each country, where the stock exchanges located or close to.

We choose 44 stock indices from 44 countries (5 continents). The overall samples are 9,239 samples from 44 countries. The list of stock market indices and weather stations is in Table 1. Table 1 also shows the beginning date of our observation.

The stock price indices used to calculate the returns. We calculate the monthly returns that we get from monthly data. For the weather data, we choose four factors; they are temperature, precipitation, hours of sunshine, and vapor pressure. We pick the stations physically closest to the cities which the stock exchanges located. It should be considered in order to make the data valid and avoid bias.

Table 1. List of Stock Market Indices and the Weather Stations

\begin{tabular}{|c|c|c|c|c|c|c|}
\hline No & Country & Stock Index & Station & $\begin{array}{c}\text { Latitude } \\
\left(0^{\prime}\right)\end{array}$ & $\begin{array}{c}\text { Elevation } \\
(\mathrm{m})\end{array}$ & $\begin{array}{l}\text { Start } \\
\text { Date }\end{array}$ \\
\hline \multicolumn{7}{|c|}{ AMERICA } \\
\hline 1 & Canada & Toronto Stock Exchange & Toronto & 43.4 & 113 & 1979 \\
\hline 2 & Argentina & Merval Buenos Aires MERV & Cordoba Aero & 31.19 & 484 & 1996 \\
\hline 3 & Chile & IPSA Santiago de Chile & Temuco & 38.46 & 93 & 2002 \\
\hline 4 & Mexico & IPC MXX & Guanajuato & 21 & 1999 & 1994 \\
\hline 5 & Columbia & Columbia IGBC Index & Bogota Eldorado & 4.42 & 2547 & 2001 \\
\hline 6 & Venezuela & Venezuela SE General & Merida & 8.36 & 1498 & 1993 \\
\hline \multicolumn{7}{|c|}{ EUROPE } \\
\hline 7 & UK & London Stock Exchange Group & Eskdalemuir & 55.19 & 242 & 2001 \\
\hline 8 & Germany & HDAX Index Perf & Berlin Tegel & 52.34 & 37 & 1996 \\
\hline 9 & Switzerland & SMI & Basel & 47.33 & 317 & 1990 \\
\hline 10 & Spain & IBEX 35 & Madrid Barajas & 40.3 & 633 & 1993 \\
\hline 11 & Netherlands & EURONEXT 100 & De Bilt & 52.06 & 4 & 2000 \\
\hline 12 & Russia & Moscow Interbank Currency Exchange & Moskva & 55.5 & 156 & 1997 \\
\hline 13 & Greece & Athens Comp Ind Tot & Heraklion & 35.2 & 39 & 2002 \\
\hline 14 & France & CAC 40 & Rennes & 48.04 & 43 & 1990 \\
\hline 15 & Austria & ATX & Kremsmuenster & 48.03 & 389 & 1992 \\
\hline 16 & Ireland & ISEQ-Overall Price & Malin Head & 55.22 & 25 & 1997 \\
\hline 17 & Italy & IPC MXX & Termoli & 42 & 44 & 2002 \\
\hline 18 & Croatia & Croatia Zagreb Crobex & Zagreb Gric & 45.49 & 162 & 1997 \\
\hline 19 & Lithuania & OMX Vilnius All-Share Index & Vilnius & 54.38 & 162 & 2000 \\
\hline 20 & Malta & MALTEX & Luqa & 35.51 & 91 & 2003 \\
\hline 21 & Portugal & Portugal PSI 20 Index & Lisboa Geof & 38.43 & 95 & 2000 \\
\hline 22 & Romania & Bucharest BET Index & Varfu Omul & 45.27 & 2509 & 1999 \\
\hline 23 & Slovenia & SBI TOP & Ljubljana Bezigrad & 46.04 & 299 & 2006 \\
\hline
\end{tabular}


Table 1 continued

\begin{tabular}{|c|c|c|c|c|c|c|}
\hline No & Country & Stock Index & Station & $\begin{array}{c}\text { Latitude } \\
\left(0^{\prime}\right)\end{array}$ & $\begin{array}{c}\text { Elevation } \\
(\mathrm{m})\end{array}$ & $\begin{array}{l}\text { Start } \\
\text { Date }\end{array}$ \\
\hline 24 & Ukraine & PFTS Stock Exchange & Kiev & 50.24 & 167 & 2001 \\
\hline 25 & Hungary & Budapest BUX & Budapest & 46 & 203 & 1991 \\
\hline 26 & Slovakia & Slovakia SAX 16 & Poprad Tatry & 49.04 & 696 & 1996 \\
\hline 27 & Luxembourg & Luxembourg SE General & Luxembourg Airport & 49.37 & 376 & 1999 \\
\hline \multicolumn{7}{|c|}{ ASIA } \\
\hline 28 & Japan & Nikkei 225 & Tokyo & 35.41 & 36 & 1984 \\
\hline 29 & South Korea & KOSPI Composite Index & Seoul & 37.34 & 86 & 1997 \\
\hline 30 & China & SSE Composite Index & Shang Hai & 31.24 & 8 & 1993 \\
\hline 31 & Hong Kong & Hang Seng China Enterprises & Kowloon & 22.19 & 66 & 1993 \\
\hline 32 & Singapore & STI Index & Changi Airport & 1.22 & 16 & 1987 \\
\hline 33 & Thailand & Bangkok SET & Bangkok & 13.44 & 4 & 1975 \\
\hline 34 & India & CNX NIFTY & New Delhi & 28.35 & 216 & 2007 \\
\hline 35 & Israel & TEL AVIV 100 & Har Knaan & 32.58 & 934 & 2000 \\
\hline 36 & Turkey & BIST 100 Index & Isparta & 37.45 & 997 & 1997 \\
\hline 37 & Kazakhstan & MSCI Kazakhstan & Astana & 51.08 & 350 & 2005 \\
\hline \multicolumn{7}{|c|}{ AUSTRALIA } \\
\hline 38 & Australia & All Ordinaries & Sydney Airport & 33.56 & 6 & 1984 \\
\hline 39 & New Zealand & NZX 50 Index Gross & Gisborne Aerodrome & 38.39 & 5 & 2003 \\
\hline \multicolumn{7}{|c|}{ AFRICA } \\
\hline 40 & Egypt & EGX 30 Index & Mersa Matruh & 31.2 & 28 & 1998 \\
\hline 41 & Mauritius & SEMDEX & Plaisance & 20.26 & 57 & 1989 \\
\hline 42 & South Africa & FTSE/JSE All Share & Bloemfontein Airport & 29.06 & 1359 & 1995 \\
\hline 43 & Morocco & Morocco All Share MASI & Rabat Sale & 34.3 & 86 & 2002 \\
\hline 44 & Tunisia & Tunisia TUNINDEX & Jendouba & 36.29 & 144 & 1998 \\
\hline
\end{tabular}

Source: www.ncdc.noaa.gov, processed

\section{Research Design and Methodology}

The study is causal research because it explains the causal relationship between the variables in the empirical model developed by researchers that is related to the influence of the variables affecting the stock market return. Based on the approach, this research is a quantitative research/positivism that emphasizes the combination of deductive logic and the use of quantitative tools in interpreting a phenomenon objectively (Balnaves \& Caputi, 2001).

There are three kinds of variables used in this study, namely dependent variables, independent variables, and control variables. The dependent variable is the stock market return which can be interpreted in indices return from 16 countries. While the independent variables are four weather factors, they are temperature, precipitation, hours of sunshine, and vapor pressure. We also use other control variables to make the groupings, such as latitude, region, pole, and elevation to represent the geographical location. Table 2 until Table 7 display numbers of summary statistics that describe the samples. Table 2 displays the summary statistics of the stock market return in each country. Table 3 until Table 6 show summary statistics of weather variables, they are Table 3 displays the summary of statistics of temperature each country, Table 4 displays the summary of statistics of precipitation each country, Table 5 displays the summary of statistics of hours of sunshine each country, and Table 6 displays the summary of statistics of vapor pressure each country. The last one, Table 7, displays summary statistics of geographical location. 
The Influence of Weather Factors to Mood and Human Behavior on the Stock Market Indices Performance by the Tendency towards Geographical Location

Table 2. Summary Statistics - Stock Market Returns

\begin{tabular}{|c|c|c|c|c|c|}
\hline Country & Mean & Median & Std Deviation & Min & Max \\
\hline \multicolumn{6}{|c|}{ AMERICA } \\
\hline Canada & 0.006 & 0.010 & 0.046 & -0.226 & 0.143 \\
\hline Argentina & 0.017 & 0.016 & 0.110 & -0.391 & 0.487 \\
\hline Chile & 0.009 & 0.006 & 0.047 & -0.096 & 0.161 \\
\hline Mexico & 0.014 & 0.016 & 0.071 & -0.295 & 0.193 \\
\hline Columbia & 0.020 & 0.019 & 0.069 & -0.223 & 0.174 \\
\hline Venezuela & 0.039 & 0.019 & 0.116 & -0.401 & 0.490 \\
\hline \multicolumn{6}{|c|}{ EUROPE } \\
\hline United Kingdom & 0.019 & 0.013 & 0.102 & -0.353 & 0.431 \\
\hline Germany & 0.008 & 0.018 & 0.063 & -0.246 & 0.208 \\
\hline Switzerland & 0.008 & 0.012 & 0.045 & -0.189 & 0.137 \\
\hline Spain & 0.004 & 0.009 & 0.077 & -0.700 & 0.166 \\
\hline Netherlands & 0.000 & 0.012 & 0.051 & -0.173 & 0.126 \\
\hline Russia & 0.023 & 0.021 & 0.131 & -0.476 & 0.490 \\
\hline Greece & 0.003 & 0.009 & 0.088 & -0.278 & 0.219 \\
\hline France & 0.004 & 0.012 & 0.055 & -0.175 & 0.134 \\
\hline Austria & 0.007 & 0.012 & 0.061 & -0.278 & 0.145 \\
\hline Ireland & 0.003 & 0.011 & 0.060 & -0.210 & 0.195 \\
\hline Italy & 0.001 & 0.012 & 0.057 & -0.157 & 0.191 \\
\hline Croatia & 0.007 & 0.006 & 0.092 & -0.451 & 0.391 \\
\hline Lithuania & 0.007 & 0.015 & 0.059 & -0.197 & 0.150 \\
\hline Malta & 0.007 & 0.013 & 0.113 & -0.896 & 0.396 \\
\hline Portugal & -0.002 & -0.002 & 0.054 & -0.194 & 0.119 \\
\hline Romania & 0.020 & 0.019 & 0.098 & -0.315 & 0.406 \\
\hline Slovenia & -0.004 & -0.003 & 0.063 & -0.178 & 0.174 \\
\hline Ukraine & 0.022 & 0.009 & 0.126 & -0.302 & 0.572 \\
\hline Hungary & 0.015 & 0.015 & 0.097 & -0.349 & 0.698 \\
\hline Slovakia & 0.002 & 0.003 & 0.061 & -0.185 & 0.364 \\
\hline Luxembourg & 0.002 & 0.006 & 0.074 & -0.312 & 0.188 \\
\hline \multicolumn{6}{|c|}{ ASIA } \\
\hline Japan & 0.003 & 0.006 & 0.061 & -0.238 & 0.201 \\
\hline South Korea & 0.009 & 0.008 & 0.091 & -0.272 & 0.488 \\
\hline China & 0.009 & 0.002 & 0.123 & -0.288 & 1.352 \\
\hline Hong Kong & 0.011 & 0.005 & 0.115 & -0.267 & 0.519 \\
\hline Singapore & 0.007 & 0.011 & 0.066 & -0.239 & 0.282 \\
\hline Thailand & 0.009 & 0.005 & 0.085 & -0.314 & 0.489 \\
\hline India & 0.006 & 0.006 & 0.080 & -0.264 & 0.281 \\
\hline Israel & 0.008 & 0.015 & 0.056 & -0.176 & 0.152 \\
\hline Turkey & 0.033 & 0.019 & 0.146 & -0.445 & 0.970 \\
\hline Kazakhstan & 0.018 & 0.008 & 0.151 & -0.302 & 0.914 \\
\hline \multicolumn{6}{|c|}{ AUSTRALIA } \\
\hline Australia & 0.007 & 0.012 & 0.047 & -0.424 & 0.150 \\
\hline New Zealand & 0.007 & 0.010 & 0.035 & -0.119 & 0.087 \\
\hline \multicolumn{6}{|c|}{ AFRICA } \\
\hline Egypt & 0.015 & 0.011 & 0.104 & -0.301 & 0.393 \\
\hline Mauritius & 0.011 & 0.008 & 0.048 & -0.177 & 0.254 \\
\hline South Africa & 0.012 & 0.014 & 0.058 & -0.293 & 0.212 \\
\hline Morocco & 0.008 & 0.005 & 0.048 & -0.124 & 0.238 \\
\hline Tunisia & 0.009 & 0.006 & 0.040 & -0.157 & 0.188 \\
\hline
\end{tabular}

Source: Data Stream, processed 
Table 3. Summary Statistics - Weather Variables, Temperature $\left({ }^{\circ} \mathrm{C}\right)$

\begin{tabular}{|c|c|c|c|c|c|}
\hline Country & Mean & Median & Std Deviation & Min & Max \\
\hline \multicolumn{6}{|c|}{ AMERICA } \\
\hline Canada & 8.210 & 7.950 & 9.022 & -11.100 & 23.000 \\
\hline Argentina & 18.512 & 19.500 & 4.618 & 8.800 & 26.600 \\
\hline Chile & 12.638 & 12.200 & 3.770 & 4.600 & 20.200 \\
\hline Mexico & 19.547 & 14.000 & 2.778 & 14.000 & 25.100 \\
\hline Columbia & 14.101 & 14.100 & 0.800 & 11.600 & 16.100 \\
\hline Venezuela & 21.271 & 21.300 & 0.845 & 19.000 & 24.000 \\
\hline \multicolumn{6}{|c|}{ EUROPE } \\
\hline United Kingdom & 7.821 & 7.800 & 4.425 & -2.600 & 16.500 \\
\hline Germany & 10.233 & 10.400 & 7.065 & -4.800 & 24.000 \\
\hline Switzerland & 10.994 & 10.700 & 6.707 & -1.400 & 24.100 \\
\hline Spain & 10.770 & 0.166 & 8.442 & 0.000 & 27.700 \\
\hline Netherlands & 10.374 & 10.150 & 5.514 & -1.500 & 21.900 \\
\hline Russia & 6.194 & 6.400 & 9.984 & -14.600 & 25.700 \\
\hline Greece & 18.639 & 17.900 & 5.205 & 9.800 & 27.100 \\
\hline France & 12.668 & 12.600 & 5.803 & 1.400 & 24.600 \\
\hline Austria & 9.731 & 9.950 & 7.537 & -4.900 & 22.100 \\
\hline Ireland & 10.102 & 10.000 & 3.321 & 3.700 & 17.400 \\
\hline Italy & 16.048 & 15.600 & 6.711 & 5.500 & 28.100 \\
\hline Croatia & 12.380 & 12.800 & 7.917 & -1.200 & 26.100 \\
\hline Lithuania & 7.265 & 7.700 & 8.682 & -13.400 & 21.700 \\
\hline Malta & 19.254 & 18.350 & 5.447 & 10.300 & 28.800 \\
\hline Portugal & 17.865 & 17.550 & 4.260 & 10.600 & 25.600 \\
\hline Romania & -1.541 & -1.400 & 6.658 & -14.700 & 10.900 \\
\hline Slovenia & 12.104 & 12.500 & 7.616 & -1.500 & 23.700 \\
\hline Ukraine & 9.020 & 9.450 & 9.428 & -13.100 & 26.900 \\
\hline Hungary & 11.520 & 12.050 & 8.081 & -5.800 & 25.700 \\
\hline Slovakia & 6.995 & 7.750 & 7.830 & -9.500 & 18.500 \\
\hline Luxembourg & 9.911 & 9.800 & 6.513 & -2.600 & 23.700 \\
\hline \multicolumn{6}{|c|}{ ASIA } \\
\hline Japan & 16.585 & 17.100 & 7.593 & 3.200 & 30.200 \\
\hline South Korea & 12.865 & 14.600 & 9.640 & -5.700 & 27.400 \\
\hline China & 17.500 & 18.700 & 8.502 & 0.000 & 32.000 \\
\hline Hong Kong & 22.894 & 0.519 & 5.032 & 0.000 & 29.300 \\
\hline Singapore & 27.630 & 27.700 & 0.765 & 25.500 & 29.500 \\
\hline Thailand & 29.127 & 29.200 & 1.422 & 23.700 & 32.700 \\
\hline India & 25.472 & 27.300 & 6.771 & 12.800 & 36.100 \\
\hline Israel & 17.036 & 17.950 & 6.424 & 4.900 & 27.700 \\
\hline Turkey & 12.706 & 12.050 & 7.582 & -1.100 & 26.200 \\
\hline Kazakhstan & 3.902 & 6.100 & 13.809 & -23.000 & 24.300 \\
\hline \multicolumn{6}{|c|}{ AUSTRALIA } \\
\hline Australia & 18.472 & 18.800 & 3.742 & 11.700 & 25.100 \\
\hline New Zealand & 14.411 & 14.200 & 3.525 & 8.700 & 21.000 \\
\hline \multicolumn{6}{|c|}{ AFRICA } \\
\hline Egypt & 20.299 & 20.100 & 4.562 & 12.500 & 27.600 \\
\hline Mauritius & 24.207 & 24.200 & 2.070 & 20.400 & 27.700 \\
\hline South Africa & 16.348 & 17.300 & 5.386 & 6.200 & 24.200 \\
\hline Morocco & 15.668 & 4.200 & 6.823 & 4.200 & 27.800 \\
\hline Tunisia & 18.812 & 18.150 & 6.914 & 6.300 & 31.400 \\
\hline
\end{tabular}

Source: www.ncdc.noaa.gov, processed 
The Influence of Weather Factors to Mood and Human Behavior on the Stock

Market Indices Performance by the Tendency towards Geographical Location

Table 4. Summary Statistics - Weather Variables, Precipitation (mm)

\begin{tabular}{|c|c|c|c|c|c|}
\hline Country & Mean & Median & Std Deviation & Min & Max \\
\hline \multicolumn{6}{|c|}{ AMERICA } \\
\hline Canada & 70.411 & 65.750 & 35.384 & 4.400 & 209.200 \\
\hline Argentina & 632.130 & 411.000 & 681.303 & 0.000 & 3488.000 \\
\hline Chile & 834.229 & 694.000 & 650.759 & 5.000 & 2954.000 \\
\hline Mexico & 435.092 & 121.500 & 721.287 & 0.000 & 5903.000 \\
\hline Columbia & 648.220 & 499.500 & 598.016 & 0.000 & 3519.000 \\
\hline Venezuela & 1078.610 & 926.000 & 824.057 & 5.000 & 4223.000 \\
\hline \multicolumn{6}{|c|}{ EUROPE } \\
\hline United Kingdom & 153.197 & 135.200 & 80.217 & 17.600 & 431.600 \\
\hline Germany & 46.132 & 39.150 & 32.404 & 0.200 & 212.100 \\
\hline Switzerland & 69.549 & 63.200 & 40.868 & 2.000 & 196.600 \\
\hline Spain & 23.409 & 10.500 & 29.650 & 0.000 & 171.600 \\
\hline Netherlands & 77.377 & 74.600 & 40.334 & 0.500 & 223.700 \\
\hline Russia & 60.573 & 53.000 & 32.652 & 9.300 & 183.500 \\
\hline Greece & 361.947 & 190.000 & 424.813 & 0.000 & 1698.000 \\
\hline France & 50.987 & 46.200 & 31.239 & 1.000 & 203.800 \\
\hline Austria & 856.894 & 815.000 & 482.235 & 0.000 & 3399.000 \\
\hline Ireland & 903.975 & 833.000 & 403.998 & 104.000 & 2419.000 \\
\hline Italy & 628.752 & 473.000 & 514.588 & 0.000 & 2668.000 \\
\hline Croatia & 729.092 & 701.000 & 423.985 & 7.000 & 1958.000 \\
\hline Lithuania & 391.363 & 329.500 & 280.790 & 5.000 & 1816.000 \\
\hline Malta & 472.841 & 292.000 & 558.057 & 0.000 & 2593.000 \\
\hline Portugal & 666.722 & 427.500 & 727.536 & 0.000 & 3078.000 \\
\hline Romania & 738.349 & 638.000 & 453.704 & 14.000 & 2824.000 \\
\hline Slovenia & 1147.033 & 1101.000 & 669.753 & 31.000 & 4254.000 \\
\hline Ukraine & 395.500 & 290.000 & 344.579 & 1.000 & 1899.000 \\
\hline Hungary & 498.272 & 402.500 & 478.234 & 0.000 & 3110.000 \\
\hline Slovakia & 535.830 & 415.000 & 409.695 & 0.000 & 2204.000 \\
\hline Luxembourg & 730.017 & 645.500 & 384.286 & 55.000 & 1971.000 \\
\hline \multicolumn{6}{|c|}{ ASIA } \\
\hline Japan & 117.860 & 103.600 & 91.128 & 0.000 & 780.000 \\
\hline South Korea & 111.199 & 48.500 & 156.304 & 0.000 & 994.500 \\
\hline China & 96.696 & 80.200 & 81.151 & 2.300 & 570.900 \\
\hline Hong Kong & 195.445 & 111.000 & 228.902 & 0.000 & 1333.000 \\
\hline Singapore & 188.393 & 165.000 & 131.950 & 0.000 & 1364.000 \\
\hline Thailand & 1368.619 & 1034.500 & 1330.604 & 0.000 & 6206.000 \\
\hline India & 588.408 & 126.500 & 879.403 & 0.000 & 3756.000 \\
\hline Israel & 571.107 & 161.000 & 820.683 & 0.000 & 4384.000 \\
\hline Turkey & 428.186 & 309.500 & 410.560 & 0.000 & 2200.000 \\
\hline Kazakhstan & 28.134 & 22.000 & 20.284 & 2.000 & 113.000 \\
\hline \multicolumn{6}{|c|}{ AUSTRALIA } \\
\hline Australia & 88.215 & 62.200 & 81.330 & 0.000 & 581.000 \\
\hline New Zealand & 842.045 & 742.000 & 559.717 & 68.000 & 2513.000 \\
\hline \multicolumn{6}{|c|}{ AFRICA } \\
\hline Egypt & 159.770 & 13.000 & 380.372 & 0.000 & 3560.000 \\
\hline Mauritius & 1293.850 & 878.000 & 1186.995 & 10.000 & 6663.000 \\
\hline South Africa & 405.464 & 229.500 & 436.849 & 0.000 & 1758.000 \\
\hline Morocco & 144.451 & 83.000 & 172.912 & 0.000 & 1072.000 \\
\hline Tunisia & 401.005 & 309.000 & 365.545 & 0.000 & 1938.000 \\
\hline
\end{tabular}

Source: www.ncdc.noaa.gov, processed 
Table 5. Summary Statistics - Weather Variables, Hours of Sunshine (hours)

\begin{tabular}{|c|c|c|c|c|c|}
\hline Country & Mean & Median & Std Deviation & Min & Max \\
\hline \multicolumn{6}{|c|}{ AMERICA } \\
\hline Canada & 167.438 & 162.800 & 68.330 & 34.000 & 324.800 \\
\hline Argentina & 244.242 & 232.000 & 76.769 & 102.000 & 392.000 \\
\hline Chile & 177.639 & 153.000 & 90.461 & 0.000 & 357.000 \\
\hline Mexico & 224.179 & 225.000 & 41.542 & 101.000 & 330.000 \\
\hline Columbia & 128.367 & 124.500 & 34.457 & 0.000 & 236.000 \\
\hline Venezuela & 208.960 & 216.000 & 43.619 & 103.000 & 313.000 \\
\hline \multicolumn{6}{|c|}{ EUROPE } \\
\hline United Kingdom & 91.805 & 84.800 & 48.267 & 11.800 & 233.900 \\
\hline Germany & 141.835 & 134.000 & 80.867 & 15.000 & 372.000 \\
\hline Switzerland & 134.242 & 126.000 & 69.683 & 0.000 & 313.000 \\
\hline Spain & 236.348 & 239.000 & 85.452 & 71.000 & 433.000 \\
\hline Netherlands & 139.542 & 143.500 & 66.820 & 0.000 & 307.000 \\
\hline Russia & 155.798 & 140.000 & 109.716 & 5.000 & 394.000 \\
\hline Greece & 240.451 & 235.000 & 99.186 & 82.000 & 395.000 \\
\hline France & 143.789 & 142.000 & 72.718 & 21.000 & 347.000 \\
\hline Austria & 168.854 & 173.000 & 88.055 & 0.000 & 385.000 \\
\hline Ireland & 126.394 & 127.000 & 53.069 & 30.000 & 262.000 \\
\hline Italy & 197.534 & 190.000 & 84.185 & 14.000 & 352.000 \\
\hline Croatia & 166.138 & 159.000 & 83.588 & 22.000 & 334.000 \\
\hline Lithuania & 136.196 & 120.500 & 86.183 & 8.000 & 331.000 \\
\hline Malta & 248.705 & 236.000 & 74.160 & 112.000 & 386.000 \\
\hline Portugal & 237.870 & 235.000 & 81.150 & 91.000 & 384.000 \\
\hline Romania & 184.083 & 185.000 & 90.903 & 23.000 & 396.000 \\
\hline Slovenia & 165.848 & 157.500 & 94.836 & 22.000 & 349.000 \\
\hline Ukraine & 145.658 & 145.500 & 88.776 & 0.000 & 341.000 \\
\hline Hungary & 170.312 & 166.500 & 89.440 & 0.000 & 361.000 \\
\hline Slovakia & 152.274 & 150.000 & 80.384 & 0.000 & 336.000 \\
\hline Luxembourg & 149.028 & 149.500 & 85.094 & 14.000 & 346.000 \\
\hline \multicolumn{6}{|c|}{ ASIA } \\
\hline Japan & 159.987 & 161.500 & 39.374 & 39.200 & 259.200 \\
\hline South Korea & 164.360 & 169.000 & 44.741 & 34.000 & 256.000 \\
\hline China & 147.000 & 145.000 & 44.491 & 33.000 & 322.000 \\
\hline Hong Kong & 151.082 & 150.000 & 49.402 & 0.000 & 294.000 \\
\hline Singapore & 166.645 & 168.000 & 40.410 & 0.000 & 256.000 \\
\hline Thailand & 168.006 & 164.000 & 63.458 & 27.000 & 293.000 \\
\hline India & 164.211 & 167.000 & 53.103 & 45.000 & 271.000 \\
\hline Israel & 212.857 & 235.500 & 84.631 & 60.000 & 367.000 \\
\hline Turkey & 222.490 & 216.500 & 87.216 & 14.000 & 396.000 \\
\hline Kazakhstan & 206.041 & 191.000 & 96.064 & 47.000 & 395.000 \\
\hline \multicolumn{6}{|c|}{ AUSTRALIA } \\
\hline Australia & 180.801 & 199.000 & 63.496 & 53.000 & 322.000 \\
\hline New Zealand & 137.742 & 156.000 & 88.812 & 0.000 & 308.000 \\
\hline \multicolumn{6}{|c|}{ AFRICA } \\
\hline Egypt & 275.686 & 282.000 & 73.069 & 102.000 & 396.000 \\
\hline Mauritius & 208.952 & 209.000 & 42.787 & 63.000 & 326.000 \\
\hline South Africa & 266.248 & 271.000 & 37.050 & 94.000 & 354.000 \\
\hline Morocco & 230.944 & 236.000 & 66.999 & 70.000 & 350.000 \\
\hline Tunisia & 221.807 & 220.000 & 65.580 & 85.000 & 376.000 \\
\hline
\end{tabular}

Source: www.ncdc.noaa.gov, processed 
The Influence of Weather Factors to Mood and Human Behavior on the Stock Market Indices Performance by the Tendency towards Geographical Location

Table 6. Summary Statistics - Weather Variables, Vapor Pressure (mb)

\begin{tabular}{|c|c|c|c|c|c|}
\hline Country & Mean & Median & Std Deviation & Min & Max \\
\hline \multicolumn{6}{|c|}{ AMERICA } \\
\hline Canada & 7.771 & 6.500 & 5.073 & 0.400 & 19.400 \\
\hline Argentina & 12.462 & 11.800 & 3.222 & 0.000 & 22.000 \\
\hline Chile & 11.773 & 10.700 & 3.796 & 0.000 & 22.100 \\
\hline Mexico & 13.818 & 14.200 & 3.496 & 0.000 & 25.000 \\
\hline Columbia & 12.396 & 12.400 & 0.991 & 10.100 & 16.500 \\
\hline Venezuela & 37.615 & 24.800 & 39.011 & 1.000 & 238.000 \\
\hline \multicolumn{6}{|c|}{ EUROPE } \\
\hline United Kingdom & 9.554 & 8.900 & 2.689 & 4.800 & 19.000 \\
\hline Germany & 9.906 & 9.350 & 3.505 & 3.900 & 18.100 \\
\hline Switzerland & 7.129 & 6.500 & 4.795 & 0.000 & 16.900 \\
\hline Spain & 9.342 & 9.000 & 2.263 & 3.900 & 17.300 \\
\hline Netherlands & 10.614 & 9.800 & 3.485 & 1.200 & 17.900 \\
\hline Russia & 8.522 & 7.700 & 5.740 & -33.000 & 21.000 \\
\hline Greece & 15.500 & 14.800 & 4.750 & 7.300 & 26.800 \\
\hline France & 10.749 & 10.000 & 3.645 & 4.800 & 21.100 \\
\hline Austria & 10.334 & 9.550 & 4.341 & 3.800 & 18.400 \\
\hline Ireland & 10.401 & 9.950 & 2.404 & 6.100 & 18.000 \\
\hline Italy & 13.865 & 12.500 & 9.628 & 0.000 & 107.000 \\
\hline Croatia & 10.761 & 9.950 & 4.350 & 3.800 & 19.000 \\
\hline Lithuania & 8.713 & 7.700 & 4.145 & 1.100 & 20.300 \\
\hline Malta & 16.173 & 15.150 & 4.453 & 8.900 & 25.600 \\
\hline Portugal & 14.568 & 14.300 & 3.215 & 2.100 & 21.500 \\
\hline Romania & 9.942 & 9.600 & 4.449 & 0.600 & 19.000 \\
\hline Slovenia & 10.960 & 10.200 & 4.214 & 3.900 & 17.900 \\
\hline Ukraine & 9.141 & 8.100 & 4.446 & 2.700 & 17.400 \\
\hline Hungary & 10.990 & 9.500 & 16.131 & 1.300 & 269.000 \\
\hline Slovakia & 7.763 & 7.150 & 3.944 & 0.100 & 15.500 \\
\hline Luxembourg & 10.092 & 9.350 & 6.708 & 4.400 & 89.000 \\
\hline \multicolumn{6}{|c|}{ ASIA } \\
\hline Japan & 13.396 & 12.200 & 7.502 & 3.100 & 28.700 \\
\hline South Korea & 11.331 & 8.800 & 7.445 & 2.000 & 26.500 \\
\hline China & 16.724 & 14.900 & 12.228 & 0.000 & 155.000 \\
\hline Hong Kong & 22.242 & 22.800 & 7.374 & 0.000 & 32.600 \\
\hline Singapore & 30.640 & 30.700 & 1.523 & 11.000 & 33.500 \\
\hline Thailand & 28.447 & 29.900 & 3.665 & 16.000 & 34.200 \\
\hline India & 23.970 & 23.000 & 8.002 & 9.500 & 36.300 \\
\hline Israel & 12.658 & 11.300 & 4.825 & 0.000 & 27.600 \\
\hline Turkey & 9.101 & 8.550 & 3.453 & 2.000 & 17.100 \\
\hline Kazakhstan & 6.425 & 5.800 & 4.068 & 0.900 & 15.200 \\
\hline \multicolumn{6}{|c|}{ AUSTRALIA } \\
\hline Australia & 12.379 & 11.800 & 4.927 & 0.000 & 34.000 \\
\hline New Zealand & 12.583 & 12.300 & 2.925 & 0.000 & 19.100 \\
\hline \multicolumn{6}{|c|}{ AFRICA } \\
\hline Egypt & 16.361 & 15.600 & 5.445 & 1.000 & 28.600 \\
\hline Mauritius & 23.288 & 22.800 & 4.037 & 0.300 & 32.500 \\
\hline South Africa & 10.394 & 10.100 & 4.027 & 3.800 & 31.000 \\
\hline Morocco & 16.068 & 15.350 & 3.753 & 8.600 & 25.000 \\
\hline Tunisia & 14.318 & 14.100 & 3.779 & 7.900 & 22.200 \\
\hline
\end{tabular}

Source: www.ncdc.noaa.gov, processed 
Table 7. Summary Statistics - Geographical Location Variables

\begin{tabular}{lccccc}
\hline \multicolumn{1}{c}{ Variables } & Mean & Median & Std Deviation & Min & Max \\
\hline Latitude & 37.527 & 38.410 & 13.574 & 1.220 & 55.500 \\
\hline Region & dummy & dummy & dummy & dummy & dummy \\
\hline Pole & dummy & dummy & dummy & dummy & dummy \\
\hline Elevation & 405.023 & 150.000 & 639.492 & 4.000 & 2547.000 \\
\hline
\end{tabular}

Source: www.ncdc.noaa.gov, processed

Data are processed with models used to analyze the causal relationship between the returns of stock market indices and weather variables using GARCH Model by Eviews 7. As these several graphs in Graph 1, it showed the relation between return and four weather variables.

Return - Temperature (X1)

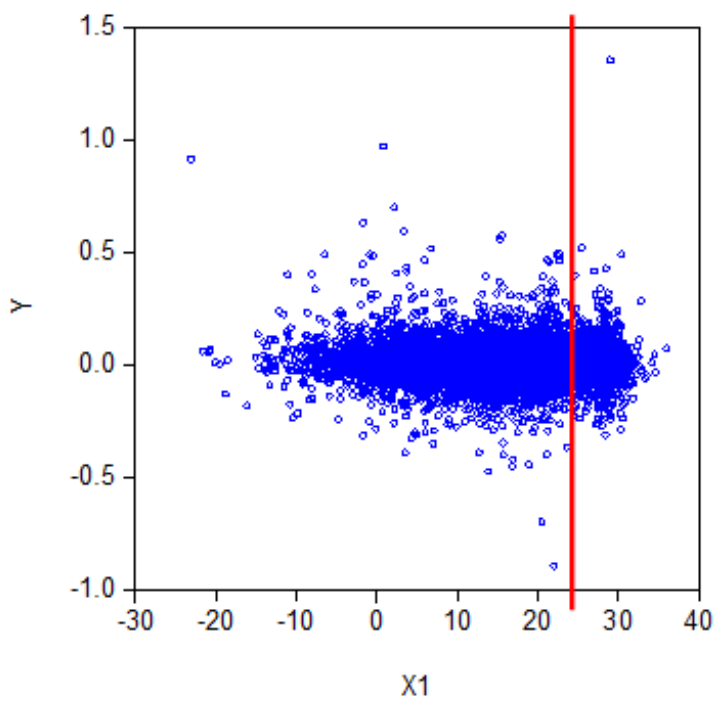

Return - Precipitation (X2)

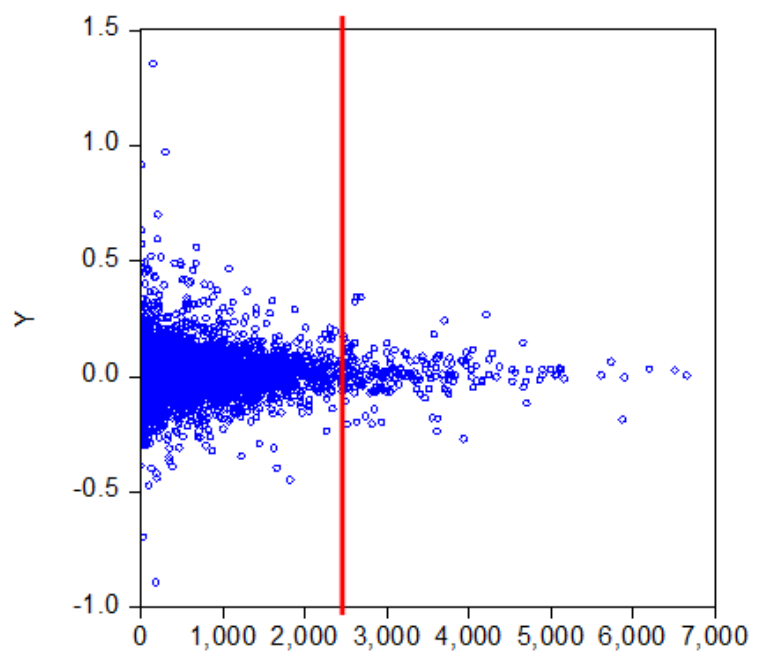

$\mathrm{X} 2$

Return - Hours of Sunshine (X3)

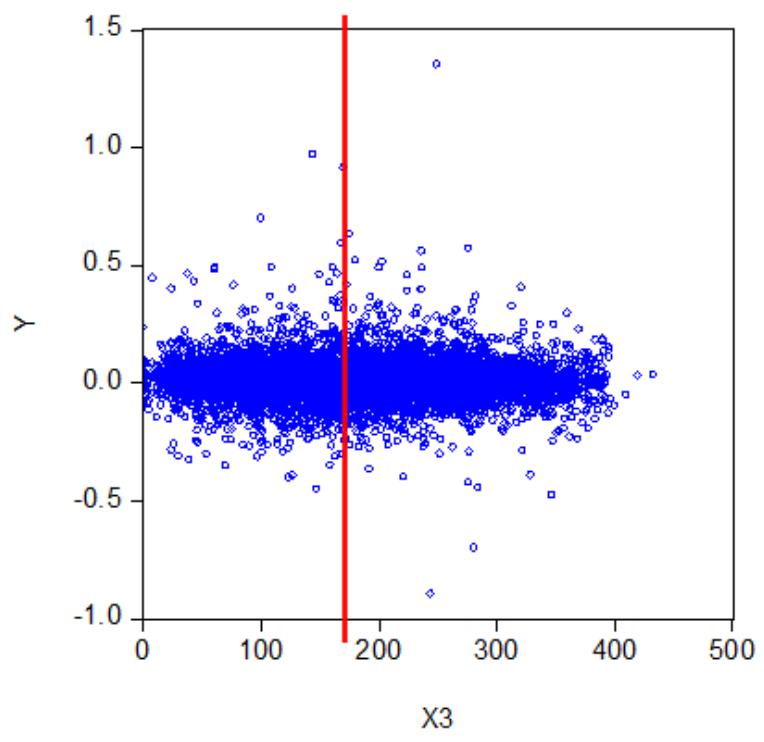

Return - Vapor Pressure (X4)

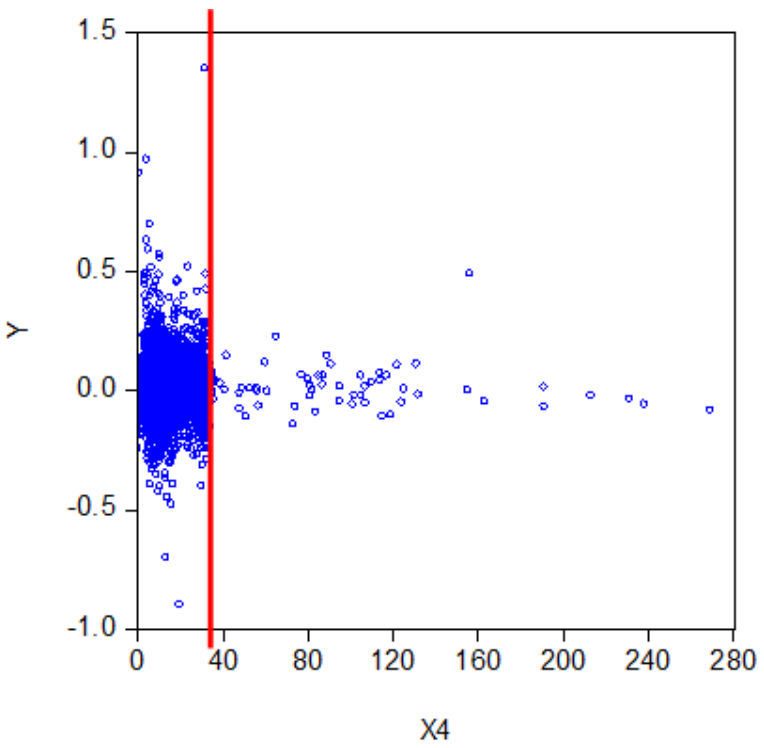

Graph 1. Relation Between Return and Weather Variables

We run all countries data into an unbalanced panel data. And the regression equation used is GARCH Model as follows:

Return equation:

$$
\mathrm{R}=\alpha_{0}+\beta_{\mathrm{i}} \mathrm{X}_{\mathrm{i}}+\varepsilon
$$


Variance equation:

$$
\begin{gathered}
\delta=\gamma_{0}+\gamma_{1} * \varepsilon(-1)^{2}+\gamma_{2} * \text { GARCH }(-1)+\gamma_{3}^{*} \text { LAT }+\gamma_{4} * \text { REG } 1 \\
+\gamma_{5} * \text { REG } 2+\gamma_{6} * \text { REG } 3+\gamma_{7} * \text { REG } 4+\gamma_{8} * \text { POLE }+ \\
\gamma_{9} * \text { ELEV }
\end{gathered}
$$

Where:

$\mathrm{R} \quad=$ Return

$\mathrm{X}_{\mathrm{i}} \quad=$ Weather variables

LAT $=$ Latitude

$\mathrm{REG}_{1}=$ Dummy variable for region, $\mathrm{US}=1$ and non-US $=$ 0

$\mathrm{REG}_{2}=$ Dummy variable for region, Europe $=1$ and non-Europe $=0$

$\mathrm{REG}_{3}=$ Dummy variable for region, Asia $=1$ and non-Asia $=0$

$\mathrm{REG}_{4}=$ Dummy variable for region, Australia $=1$ and non-Australia $=0$

POLE $=$ Dummy variable for pole, South pole $=1$ and

North pole $=0$

ELEV $=$ Elevation

$\alpha_{0} \quad=$ The magnitude of the constant

$\beta_{\mathrm{i}} \quad=$ regression coefficient

$\varepsilon \quad=$ residual/error

$\delta=$ the variance

$\gamma_{0}=$ the parameter of variance equation

And the hypotheses can be examined by t-test and F-test.

However, before running the regression, we examine it by correlation test between weather variables to identify the model or equation has correlation problem or not, even though we run all possible regressions in series combinations of these four weather variables. Table 8 shows the results of correlation between variables, and the result shows that all weather variables have significant correlation, especially temperature (X1) and hours of sunshine (X3) with $42.78 \%$ of correlation, also temperature (X1) and vapor pressure (X4) with $60.95 \%$ of correlation.

Table 8. Correlations Between Weather Variables

\begin{tabular}{ccccc}
\hline & $\mathrm{X} 1$ & $\mathrm{X} 2$ & $\mathrm{X} 3$ & $\mathrm{X} 4$ \\
\hline $\mathrm{X} 1$ & 1.000 & & & \\
& ----- & & & \\
$\mathrm{X} 2$ & $0.174^{* * *}$ & 1.000 & & \\
& $(17.059)$ & ---- & & \\
$\mathrm{X} 3$ & $0.427^{* * *}$ & $-0.078^{* * *}$ & 1.000 & \\
& $(45.497)$ & $(-7.593)$ & ----- & \\
$\mathrm{X} 4$ & $0.609^{* * *}$ & $0.219^{* * *}$ & $0.182^{* * *}$ & 1.000 \\
& $(73.884)$ & $(21.655)$ & $(17.791)$ & ---- \\
\hline
\end{tabular}

Notes: $* * *$ Significant at the $1 \%$ level, $* *$ Significant at the $5 \%$ level, and * Significant at $10 \%$ level.

\section{Empirical Results}

Table 9 displays the results of hypothesis testing, such as types of the relationship between weather variables and stock market return with geographical location as the control variable. This table shows that temperature (X1) has a significant positive impact on the stock market return with the level of significance of $1 \%$. All equations show this evidence, Eq. 1, 2, 6, 7, 8, 12, 13, and 14; it means that temperature (X1) has an absolute impact in stock returns, whatever the combinations and the conditions. It is in line with our hypothesis that says that temperature has a significant positive effect on stock market returns.

Precipitation (X2) shows a weak relationship with stock returns; we can see on the table, in Eq. 6, 10, 12, and 13, precipitation (X2) has positively significant impact on the stock return with the level of significance $5-10 \%$, but in Eq. $1,3,9$, and 15 the results do not show that it has an impact on stock market returns. This result also contradicts our hypothesis before that says that precipitation harms stock returns; it is caused by the geographical location factors used, elevation. Investors or stock markets in high elevation will not feel sceptic or worried about high precipitation or raining because great locations do not have the risk of flood happened.

Hours of sunshine show good results; all equations show that hours of sunshine (X3) have a significant positive effect on stock market returns. In Eq. 4, 9, 11, and 15 show $1 \%$ significant level, Eq. 7 and 14 show 5\% significant level, and Eq. 1 and 12 show 10\% significant level.

Vapor pressure (X4) has positively significant impact on stock market return with a degree of significance $1 \%$ showed in Eq. 5, 10, and 15, 5\% in Eq. 11. Nevertheless, in Eq. 1, 8, 13, and 14 show that it does not affect stock returns. It is because these equations are not correct; it may have a correlation problem. So, most of the results can prove our hypothesis that vapor pressure contributes positively significant impact on stock market returns.

Table 9 also shows that geographical locations have contributions to the relationship between weather variables and stock market returns, especially REG2, REG3, and ELEV. These three control variables have a significant positive impact on our models. It means REG2, in Europe the effect of weather variables is much stronger than in other continents. Stock markets in Europe are easily affected by weather factors. Also, in variable REG3, Asia stock markets are easily affected by weather variables rather than the other continents; it is because the effect of weather factor is more reliable than the others. Another geographical location factor is the elevation (ELEV), which shows that high elevation has more contribution to the effect of weather variables on stock market returns. High locations have a stronger effect, and the stock markets in high elevation are easily affected by weather than low elevation.

\section{Conclusions and Suggestions}

This study finds that weather factors influence the stock 
market return because the weather can affect mood and human Behavior. It is showed in the results of this research. The temperature has a significant positive effect on the stock market returns. This result strengthens the study found by Cao and Wei (2005). They find that low temperature tends to cause aggression and high temperature tends to cause aggression, hysteria, and apathy. Our result makes a more precise explanation about this that in the global stock market indices temperature affects more aggression and makes investors more aggressive and risk-taking, so the returns are higher, also in line with Howarth and Hoffman (1984), the high temperature makes the concentration increasing.

Another variable, precipitation, has a weak effect to the stock market returns, and it does not prove the hypothesis that precipitation has a negative impact on stock returns, which is argued by Howarth and Hoffman (1984) that precipitation affects skepticism. Some models show that it has a significant positive impact on stock returns; it caused by the geographical location factors used, elevation. Investors or stock markets in high elevation will not feel sceptic or worried about high precipitation or raining because great locations do not have a risk of flood happened.

Hours of sunshine have a significant positive effect on stock market returns. It has the same result as the previous researches. David and Tyler (2003) find that sunshine is highly significantly correlated with daily stock returns. Their research proves that people often attribute their feelings to the wrong source, leading to incorrect judgements (misattribution), likes happiness on sunny days than rainy days. Another research, Symeonidis et al. (2010) adds the volatility indices for further support to the previous finding. They conclude that sunny weather influence the mood of investors, making them more optimistic and less risk-averse, which leads to higher returns. Futhermore, Akhtari (2011) who finds that hours of sunshine in New York City have a significant correlation with stock prices and he argues that sunnier day is associated with investors being more willing to take a risky investment, such as stocks, as opposed to less risky investments.

Most results of vapor pressure show that it has a significantly positive impact on stock market return. It proves our hypothesis that comes from Howarth and Hoffman (1984) who argue that decreasing humidity and dropping barometric pressure accompanied lower score on concentration. Lower concentration tends to make lower returns.

In our research, geographical locations also have contributions to the relationship between weather variables and stock market returns. The effect of weather variables is much stronger in Europe and Asia rather than in other continents. In conclusion, stock markets in Europe and Asia are easily affected by weather factors. Another geographical location factor is the elevation, which shows that high elevation has more contribution to the effect of weather variables on stock market returns. High places have a strong effect, and the stock markets in high elevation are easily affected by weather than low elevation.

This paper still cannot prove the precipitation factors and what is the connection to the sceptic or worry about the flood. So, it needs more efforts to find the relation of these variables. Also, this paper can be developed using other weather variables. 
The Influence of Weather Factors to Mood and Human Behavior on the Stock

Market Indices Performance by the Tendency towards Geographical Location

Table 9. Relation between Stock Market Return, Weather, and Geographical Location

\begin{tabular}{|c|c|c|c|c|c|c|c|c|c|c|c|c|c|c|c|}
\hline Variable & (1) & $(2)$ & (3) & (4) & (5) & (6) & (7) & (8) & (9) & (10) & (11) & (12) & (13) & (14) & $(15)$ \\
\hline \multirow[t]{2}{*}{$\mathrm{X} 1$} & $0.000^{* * *}$ & $0.000^{* * *}$ & & & & $0.000^{* * *}$ & $0.000^{* * *}$ & $0.000^{* * *}$ & & & & $0.000^{* * *}$ & $0.000^{* * *}$ & $0.000^{* * *}$ & \\
\hline & (4.477) & $(6.096)$ & & & & (6.393) & $(4.817)$ & $(5.589)$ & & & & (5.118) & $(5.550)$ & $(4.426)$ & \\
\hline \multirow[t]{2}{*}{$\mathrm{X} 2$} & 0.000 & & 0.000 & & & $0.000^{* *}$ & & & 0.000 & $0.000^{*}$ & & $0.000^{*}$ & $0.000^{*}$ & & 0.000 \\
\hline & $(1.512)$ & & $(0.881)$ & & & (2.009) & & & $(0.521)$ & $(1.811)$ & & $(1.670)$ & $(1.802)$ & & $(1.256)$ \\
\hline \multirow[t]{2}{*}{$\mathrm{X} 3$} & $0.000^{*}$ & & & $0.000^{* * *}$ & & & $0.000^{* *}$ & & $0.000^{* * *}$ & & $0.000^{* * *}$ & $0.000^{*}$ & & $0.00 *^{* *}$ & $0.000^{* * *}$ \\
\hline & (1.790) & & & $(4.647)$ & & & $(2.216)$ & & $(4.576)$ & & $(4.073)$ & $(1.880)$ & & $(2.063)$ & $(3.847)$ \\
\hline \multirow[t]{2}{*}{$\mathrm{X} 4$} & 0.000 & & & & $0.000^{* * *}$ & & & 0.000 & & $0.000^{* * *}$ & $0.000^{* *}$ & & 0.000 & 0.000 & $0.000^{* * *}$ \\
\hline & $(0.887)$ & & & & $(3.222)$ & & & $(1.449)$ & & $(3.632)$ & $(2.376)$ & & $(1.052)$ & (1.184) & (2.678) \\
\hline \multicolumn{16}{|c|}{ Control Variable : } \\
\hline \multirow[t]{2}{*}{ LAT } & -0.000 & -0.000 & -0.000 & -0.000 & -0.000 & -0.000 & -0.000 & -0.000 & -0.000 & -0.000 & -0.000 & -0.000 & -0.000 & -0.000 & -0.000 \\
\hline & $(-1.246)$ & $(-1.291)$ & $(-1.143)$ & $(-1.149)$ & $(-1.241)$ & $(-1.349)$ & $(-1.261)$ & $(-1.192)$ & $(-1.162)$ & $(-1.303)$ & $(-1.227)$ & $(-1.317)$ & $(-1.263)$ & $(-1.185)$ & $(-1.272)$ \\
\hline \multirow[t]{2}{*}{ REG1 } & 0.000 & 0.000 & 0.000 & 0.000 & 0.000 & 0.000 & 0.000 & 0.000 & 0.000 & 0.000 & 0.000 & 0.000 & 0.000 & 0.000 & 0.000 \\
\hline & $((1.075)$ & (1.159) & (1.084) & $0.989)$ & $(1.152)$ & (1.165) & (1.099) & $(1.096)$ & $(0.992)$ & (1.167) & $(1.059)$ & (1.114) & (1.117) & $(1.051)$ & $(1.077)$ \\
\hline \multirow[t]{2}{*}{ REG2 } & $0.000^{* * *}$ & $0.000^{* * *}$ & $0.000^{* * *}$ & $0.000^{* * *}$ & $0.000^{* * *}$ & $0.000^{* * *}$ & $0.000^{* * *}$ & $0.000^{* * *}$ & $0.000^{* * *}$ & $0.000^{* * *}$ & $0.000^{* * *}$ & $0.000^{* * *}$ & $0.000^{* * *}$ & $0.000^{* * *}$ & $0.000^{* * *}$ \\
\hline & $((2.813)$ & $(2.896)$ & (3.182) & $(2.847)$ & (3.124) & $(2.985)$ & $(2.773)$ & $(2.825)$ & $(2.871)$ & $(3.219)$ & $(2.862)$ & $(2.861)$ & (2.918) & $(2.726)$ & (2.935) \\
\hline \multirow[t]{2}{*}{ REG3 } & $0.000^{* * *}$ & $0.000^{* * *}$ & $0.000^{* * *}$ & $0.000^{* * *}$ & $0.000^{* * *}$ & $0.000^{* * *}$ & $0.000^{* * *}$ & $0.000^{* * *}$ & $0.000^{* * *}$ & $0.000^{* * *}$ & $0.000^{* * *}$ & $0.000^{* * *}$ & $0.000^{* * *}$ & $0.000^{* * *}$ & $0.000^{* * *}$ \\
\hline & (3.340) & (3.395) & (3.617) & (3.434) & $(3.520)$ & (3.434) & (3.310) & (3.385) & (3.443) & (3.558) & $(3.382)$ & (3.346) & $(3.422)$ & (3.303) & (3.411) \\
\hline \multirow[t]{2}{*}{ REG4 } & $-0.000^{* * *}$ & -0.000 & -0.000 & -0.000 & -0.000 & -0.000 & -0.000 & -0.000 & -0.000 & -0.000 & -0.000 & -0.000 & -0.000 & -0.000 & -0.000 \\
\hline & $(-0.332)$ & $(-0.356)$ & $(-0.400)$ & $(-0.320)$ & $(-0.321)$ & $(-0.304)$ & $(-0.328)$ & $(-0.411)$ & $(-0.313)$ & $(-0.264)$ & $(-0.249)$ & $(-0.291)$ & $(-0.348)$ & $(-0.376)$ & $(-0.221)$ \\
\hline \multirow[t]{2}{*}{ POLE } & -0.000 & -0.000 & -0.000 & -0.000 & -0.000 & -0.000 & -0.000 & -0.000 & -0.000 & -0.000 & -0.000 & -0.000 & -0.000 & -0.000 & -0.000 \\
\hline & $(-0.953)$ & $(-0.931)$ & $(-0.771)$ & $(-0.833)$ & $(-0.845)$ & $(-0.981)$ & $(-0.948)$ & $(-0.888)$ & $(-0.841)$ & $(-0.899)$ & $(-0.902)$ & $(-0.987)$ & $(-0.943)$ & $(-0.912)$ & $(-0.933)$ \\
\hline \multirow[t]{2}{*}{ ELEV } & $0.000^{* * *}$ & $0.000^{* * *}$ & $0.000^{* * *}$ & $0.000^{* * *}$ & $0.000^{* * *}$ & $0.000^{* * *}$ & $0.000^{* * *}$ & $0.000^{* * *}$ & $0.000^{* * *}$ & $0.000^{* * *}$ & $0.000^{* * *}$ & $0.000^{* * *}$ & $0.000^{* * *}$ & $0.000^{* * *}$ & $0.000^{* * *}$ \\
\hline & $(4.265)$ & $(4.215)$ & (4.309) & $(4.495)$ & $(4.230)$ & (4.199) & $(4.297)$ & $(4.223)$ & (4.489) & (4.204) & (4.408) & $(4.262)$ & $(4.207)$ & $(4.291)$ & $(4.378)$ \\
\hline Adj- $R^{2}$ & 0.002 & 0.002 & 0.000 & 0.000 & 0.000 & 0.002 & 0.002 & 0.002 & 0.000 & 0.000 & 0.000 & 0.002 & 0.002 & 0.002 & 0.000 \\
\hline
\end{tabular}

Notes: weather data are from www.ncdc.noaa.gov and indices prices are from Data Stream. ${ }^{* *}$ Significant at the $1 \%$ level, $* *$ Significant at the $5 \%$ level, and $*$ Significant at $10 \%$ level. 


\section{REFERENCES}

[1] Ackert, L., \& Deaves, R. (2009). Behavioral Finance: Psychology, Decision-Making, and Markets: Cengage Learning.

[2] Aguado, E., \& Burt, J. E. (2007). Understanding Weather And Climate.

[3] Akerlof, G. A., \& Shiller, R. J. (2010). Animal Spirits: How Human Psychology Drives the Economy, and Why It Matters for Global Capitalism: Princeton University Press.

[4] Akhtari, M. (2011). Reassessment of the weather effect: stock prices and wall street weather. The Michigan Journal of Business, 4(1), 51-70.

[5] Baker, H. K., \& Nofsinger, J. R. (2010). Behavioral Finance: Investors, Corporations, and Markets: Wiley.

[6] Balnaves, M., \& Caputi, P. (2001). Introduction to Quantitative Research Methods: An Investigative Approach: SAGE Publications.

[7] Barry, R. G., \& Chorley, R. J. (1970). Atmosphere, weather, and climate: Holt, Rinehart and Winston.

[8] Boehm, R. G. (2002). World Geography: Texas Edition: Glencoe/McGraw-Hill School Publishing Company.

[9] Cao, M., \& Wei, J. (2005). Stock market returns: A note on temperature anomaly. Journal of Banking \& Finance, 29(6), 1559-1573. doi: http://dx.doi.org/10.1016/j.jbankfin.2004.0 6.028

[10] Continental-scale temperature variability during the past two millennia. (2013). Nature Geosci, 6(5), 339-346. doi: $10.1038 /$ ngeo1797

[11] http://www.nature.com/ngeo/journal/v6/n5/abs/ngeo1797.ht $\mathrm{ml}$ \#supplementary-information

[12] Dang, H., Gillett, N. P., Weaver, A. J., \& Zwiers, F. W. (2006). Climate change detection over different land surface vegetation classes. International Journal of Climatology.

[13] Dang, H., Gillett, N. P., Weaver, A. J., \& Zwiers, F. W. (2007). Climate Change detection over different land surface vegetation classes. International Journal of Climatology, 27(2), 211-220. doi: 10.1002/joc.1397

[14] David, H., \& Tyler, S. (2003). Good Day Sunshine: Stock Returns and the Weather. Journal of Finance, 58(3), 1009-1032.

[15] Eagles, J. M. (1994). The relationship between mood and daily hours of sunlight in rapid cycling bipolar illness. Biological Psychiatry, 36(6), 422-424. doi: http://dx.doi.org/10.1016/0006-3223(94)91216-5
[16] Finance, N. Y. I. o. (1985). The Securities industry glossary: New York Institute of Finance.

[17] George, L. (2000). Emotions in Economic Theory and Economic Behavior. American Economic Review, 90(2), 426-432.

[18] Howarth, E., \& Hoffman, M. S. (1984). A multidimensional approach to the relationship between mood and weather. British Journal of Psychology, 75, 15-23.

[19] Jones, C. P. (2007). Investments: Analysis And Management, 9Th Ed: Wiley India Pvt. Limited.

[20] Kent, D., David, H., \& Avanidhar, S. (1998). Investor Psychology and Security Market Under- and Overreactions. Journal of Finance, 53(6), 1839-1885.

[21] Kliger, D., \& Levy, O. (2003). Mood-induced variation in risk preferences. Journal of Economic Behavior \& Organization, 52(4), 573-584. doi:http://dx.doi.org/10.1016 /S0167-2681(03)00069-6

[22] Lucey, B. M., \& Dowling, M. M. (2005). The Role of Feelings in Investor Decision-Making. Journal of Economic Surveys, 19(2), 211-237.

[23] Mehra, R., \& Sah, R. (2002). Mood fluctuations, projection bias, and volatility of equity prices. Journal of Economic Dynamics and Control, 26(5), 869-887. doi: http://dx.doi.org/10.1016/S0165-1889(01)00035-5

[24] Reilly, F. K., \& Brown, K. C. (2000). Investment Analysis and Portfolio Management: Dryden Press.

[25] Saunders, E. M., Jr. (1993). Stock Prices and Wall Street Weather. American Economic Review, 83(5), 1337-1345.

[26] Schwarz, N., \& Clore, G. L. (1996). Feelings and phenomenal experiences. Social psychology: Handbook of basic principles, (eds.) Arie W. Kruglanski and E. Tory Higgins, 385-407.

[27] Symeonidis, L., Daskalakis, G., \& Markellos, R. N. (2010). Does the weather affect stock market volatility? Finance Research Letters, 7(4), 214-223.

[28] Tietjen, G. H., \& Kripke, D. F. (1994). Suicides in California (1968-1977): Absence of seasonality in Los Angeles and Sacramento counties. Psychiatry Research, 53(2), 161-172. doi: http://dx.doi.org/10.1016/0165-1781(94)90107-4

[29] Vajda, A., \& Venalainen, A. (2003). The influence of natural conditions on the spatial variation of climate in Lapland, Northern Finland. International Journal of Climatology, 23, 1011-1022. doi: 10.1002/joc. 928

[30] Wallace, C. (2010, May 12, 2010). Using behavioral finance to better understand the psychology of investors. Institutional Investor. 